\title{
Confidentiality of HIV diagnosis: should we tell this family?
}

Florence Kossman-Michon, RN, Nurse member, Ethical Committee, Garches Hospital, Paris, France ( $\bullet$ ) Marie-France Bouchet, (translator), member of French Intensive Care Nurse Association (SFISI), France Daniel Benlahouès, (translator), member of French Intensive Care Nurse Association (SFISI), France

Florence Kossman-Michon, SFISI, 9 rue Crocé Spinelli, 75014 Paris, France. e-mail: SFISI@wanadoo.fr

\section{BACKGROUND}

Every year in January, during the critical care conference, at the CNIT of Paris, an ethical session is organised by the ethical committee members of SRLF (French Language Resuscitation Society). The aim of the session is to resolve the ethical problems found during a real clinical example but above all to build the process of ethical reflection. The following clinical case is based on an ethical session held at the Annual SRLF Ethic Committee Conference in January 1999.

\section{CLINICAL CASE}

Mr M., 38 years old with no significant previous medical history, was admitted to the critical care unit with acute respiratory failure. He is married with an 18-month-old son.

A diagnosis of pulmonary infection (Pneumocystis carinii pneumonia), suggesting a primary infection of human immunodeficiency virus (HIV) was made. As Mr M. was expected to recover, the critical care team decided that $\mathrm{Mr} \mathrm{M}$. should be able to give his initial diagnosis of pneumonia to his wife personally.

However, Mr M.'s condition deteriorated rapidly and he required respiratory ventilation with deep sedation. During this period, the suspected diagnosis of HIV infection was confirmed, but it was not possible to inform the patient due to his level of sedation. The team decided to inform the patient's wife of the diagnosis of pneumonia. When she was told she became very anxious because her son had been feverish for 10 days and had already had several ear, nose and throat infections during the previous year.

\section{ETHICAL PROBLEMS}

1. Should Mrs M. be told that her husband has HIV infection?

2. Is it ethical to inform Mr M.'s wife of the HIV infection, despite medical confidentiality?

3. Does concealing the diagnosis of HIV infection from the patient's wife, and the rest of the medical team, create a danger of infection?

\section{DISCUSSION}

Various speakers discussed their approaches to these dilemmas.
The discussion is summarised below.

\section{The doctor}

The resuscitator summarised his arguments in favour of revealing the diagnosis:

1. Not knowing the HIV diagnosis is unhelpful to anyone at risk of exposure.

2. There is the wider interest of public health.

3. The patient's wife does not know the diagnosis.

4. The patient is unable to tell his wife because he is sedated.

5. The wife will then be able to take precautions against infection for herself and their son.

His arguments against revealing the diagnosis were as follows:

1. Ethical framework: medical confidentiality means that the doctor is not allowed to reveal the diagnosis to the wife without Mr M.'s permission.

2. Legal: patients with HIV infection or AIDS should be treated the same way as patients with other conditions.

3. Philosophical: respect for the patient's autonomy.

4. Medical: there is no immediate danger to the patient's wife and their son.

\section{The philosopher}

The philosopher's approach was to emphasise the patient's right of autonomy. He argued that the wife must not be informed of her husband's pathology, and that it was Mr M.'s right to decide whether or not to inform his wife about his health. This corresponds to the rights of personal freedom and the principles of autonomy. This attitude differs in general from the paternalist attitude of many of the doctors. The concept of autonomy in European philosophy originates from Rousseau at the political level and from Kant at the moral level. Autonomy enables a person to give to oneself the law of its action.

\section{The lawyer}

Medical confidentiality is considered to be more important than not providing help to those at risk of infection. Nothing or noone can command the doctor to give up the principle of medical confidentiality. However, extenuating circumstances may allow 
the doctor to break his medical confidentiality. This includes the need to protect others, but this should be regarded as an unusual step. A balance is required, as doctors need to maintain the confidentiality of an individual but are also required to protect society as a whole.

\section{The nurse}

Four questions were asked by the nurse:

1. Is it right to respect medical confidentiality when there is a danger of infection for the close relations and therefore a lost opportunity to deal proactively with the risk of infection?

2. As a nurse, can we take into account the wife's suffering and concern for her husband?

3. If the diagnosis is not revealed, will the family have the right to lodge a complaint against the critical care team for not providing help to those at risk of infection?

4. Is there a conflict between the legislation that describes HIV infection and AIDS as a special case and other legislation which states that patients with HIV infection and AIDS must be treated like any other patient with an infection?

\section{CONCLUSION}

The main argument against revealing the diagnosis of HIV is:
- There is no immediate need to reveal the diagnosis. Based on the fact that $\mathrm{Mr} \mathrm{M}$. may recover, it is preferable to wait until his condition improves and he can be involved in revealing the diagnosis himself.

The main arguments for immediately revealing the diagnosis of HIV are:

- In caring for Mr M., we are also required to preserve the physical and mental health of the patient's family.

- It is inhuman to wait longer.

- We have to explain to Mrs M. that medical confidentiality is being broken for her own good and that of their son.

- To prepare Mr M.'s wife for the diagnosis, it can be revealed step by step.

- It is reasonable to assume that $\mathrm{Mr} \mathrm{M}$. would agree with taking this protective and preventive action towards his family.

Finally, the aim of the SRLF's ethical session meetings is not to find a definitive answer for any particular situation, but to help promote exchange and discussion between the different members, and approaches, of the critical care team. It is of fundamental importance that a nurse is able to take part in such ethical exchanges and in the decision made. This is part of the privileged relationship with patients and their families.

\section{GONFERENGE GONNEGTIONS}

National Conference 2001

British Association of Critical Care Nurses

Bournemouth International Centre, Bournemouth, UK.

September 16-18, 2001

Email:baccn.icms@dial.pipex.com; www.baccn.org.uk

19th Annual Symposium of the Belgium SIZ Nursing

Association

Gilly, Belgium. October 23-24, 2001

Information from: Jacqueline Massart, Rue Docteur Schweitzer,

19 Belgium. Tel/Fax: +32 (0) 71470283

8th World Congress of Intensive and Critical Care Medicine Sydney, Australia. October 28-November 1, 2001

Congress Secretariat: GPO Box 2609, Sydney NSW, Australia.

Tel: +61 29241 1478; Fax: +61 29251 3552;

E-mail:iccm@icmsaust.com.au;www.iccm.aust.com

Autumn Conference 2001

The Danish Association of Critical Care Nurses and Nurse Anaesthetists

Hotel Scanticon, Comwell, Kolding. November 12-14, 2001

Information from: Anette_Povey@hotmail.com

National Association of Critical Care Area Nurses - Italy 20th ANIARTI National Conference

Congresses Palace, Rimini, Italy. November 14-16, 2001

Information from: ANIARTI, Via Val di Sieve 32,

50127 Firenze, Italy.E-mail:aniarti@aniarti.it;

www.aniarti.it
Care of the Newborn: Neonatology Symposium 2001

Neonatal Infections

Utrecht, The Netherlands. December 3, 2001

Information from: Mrs J de Vos, Nurse manager NICU, UMC Utrecht, location WKZ. PO Box 85090, 3508 AB Utrecht, The Netherlands.E-mail:J.deVos@azu.nl

\section{2nd European Conference on Management of Coronary} Heart Disease

Nice, France. April 13-15, 2002

Information from: Castle House Medical Conferences, Quint House, Nevill Ridge, Nevill Park, Tunbridge Wells, Kent TN4 8NN, UK. Tel: +44 1892 539606; Fax: +44 1892517773 ; E-mail: cardiology@castlehouse.co.uk; www.castlehouse.co.uk/coron $2 /$ index.htm

Spring Conference 2002

1st Conference of the European Federation of Critical Care Nursing Associations

Disneyland $^{\circledR}$, Paris, France. May 26-27, 2002

Information from: Index Communications, Crown House, 28 Winchester Road, Romsey, SO51 8AA.

Tel: +44 1794 511331; Fax: +44 1794 511455; www.efccna.org

8th Symposium of European Society of Paediatric and Neonatal Intensive Care

Göteborg, Sweden. September 13-14, 2002

Information from: Monica Johnson, PICU-Avd 328, The Queen Silvia Children's Hospital, S-41685 Göteborg, Sweden.

Tel: +46313434 746; Fax: +463134355884 